\title{
Practical Guide to Clinical Data Management by Susanne Prokscha, 2007.
}

Practical Guide to Clinical Data Management, Susanne Prokscha. 2007. ISBN-13: 978-0-8493-7615-3

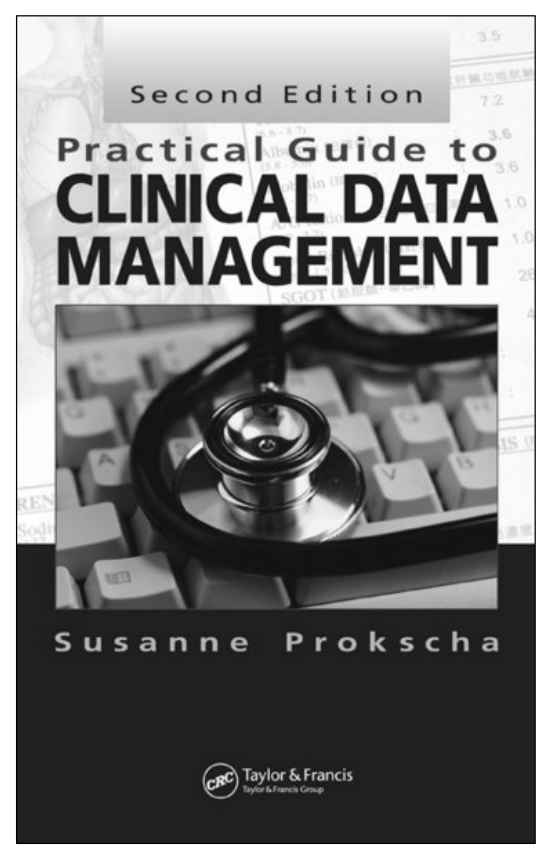

임상시험 데이터란 21세기 바인오 핵식산업인 신약 개발과 새로운 의료기기 개발을 위한 유효성과 안정 성을 시험할 때 생성되거나 임상연구 과정에서 도출 된 모든 데이터를 의미한다. 이러한 데이터는 제약사 또는 의료 기기 회사들이 수많은 자본을 투자해서 생 성한 것으로 관련 기업이나 기관에게는 매우 중요한 자산이라고 할 수 있다. 이는 신규 개발 제품이나 약 품으로부터 이익을 창출할 수 있도록 하는 것은 바로 이러한 데이터로부터 출발하기 때문이다. 임상시험 데이터 관리는 데이터의 수집으로부터 시작해서 분석 을 위해 추출하는 단계를 모두 포함하는 것으로 허가 나 심의를 위해 데이터를 제출하고 최종 승인을 얻는
과정에서 매우 중요한 요소가 되고 있다. 이와 같이 데이터 관리의 중요성이 중요함에도 불구하고 1970년 대와 1980년대에는 임상 시험 데이터 관리(Clinical Data Management)를 보조적 업무로 인식하였으나 최 근 컴퓨터 활용이 증가하면서 매우 전문적인 분야로 변화하고 있다.

이와 같은 흐름에서 Food and Drug Administration (FDA)가 제정한 $21 \mathrm{CFR} 11$ 의 “전자 자료; 전자 서명 (Electronic Records; Electronic Signatures)"은 임상데이 터 관리에 많은 영향을 미치고 있다. 데이터 관리자의 입장에서는 이 법규 제정된 이후로 $21 \mathrm{CFR} 11$ 을 준 수하기 위해 더욱 많은 노력이 필요하게 되었지만 오 히려 데이터 관리를 위한 기본적인 요구사항과 목표 는 매우 명확해졌다.

한편 데이터 관리 측면에서 최근 나타나고 있는 큰 변화는 증례기록지를 정보시스템을 이용하여 수집, 관리하는 전자 자료 수집(Electronic Data Capture) 시 스템의 사용이 훨씬 증가하였다는 점이다. 해외의 경 우 그 증가율이 매년 $15 \%$ 이상이라는 보고가 있으며 2007 년도에 수행된 임상 시험의 약 $50 \%$ 이상이 $\mathrm{EDC}$ 를 이용하거나 $\mathrm{EDC}$ 와 종이를 동시에 사용하고 있다 고 한다. 국내의 경우 아직은 몇몇 회사들만이 $\mathrm{EDC}$ 시스템을 시도하고 있으나 본 책에서는 데이터 관리 측면에 있어서 $\mathrm{EDC}$ 에 기반을 한 연구와 종이문서에 기반을 한 연구들 간의 차이점과 유사점을 고찰하고 자 한다. 이는 오늘날의 데이터 관리자들은 두 가지 연구의 처리방식을 모두 이해하여 연구 특성에 따라 선택하고 적절한 데이터 관리 방법을 설계할 수 있어 야 하기 때문이다.

이 책은 총 3 부로 구성되어 있다. 제 1 부는 모든 데 이터 관리자들이 알아야 하고 모든 데이터 관리자들 
이 다루어야 하는 기초적인 자료관리 업무에 대해 서 술하고 있다. 1 장은 데이터 관리 절차의 거의 모든 경 우에 공통적으로 포함되는 요소들이나 단계들에 대해 다루고 있다. 규모와 역사에 상관없이 어떤 데이터 관 리팀도 이에 대한 과제를 수행하거나 밀접하게 연구 해야 한다. 모든 데이터 관리 업무를 연구 기관에 이 관시켜서 내부적으로 데이터 관리를 하지 않는 회사 라 하더라도 이 요소들에 대해 인지해야 하며 그 요 소들이 수행될 때 감독할 필요가 있다.

제2부는 규정된 환경에서 데이터관리 작업을 수행 하는데 필요한 기반 구조를 중점적으로 다룬다. 적절 한 기반구조가 갖추어져 있지 않으면 데이터관리 그 룹은 일관성 있는 작업을 수행할 수 없으며 FDA (Food and Drug Administration) 규정도 준수할 수 없 다. 표준 업무 절차(Standard Operating Procedure), 교 육, 보안을 다룬 처음 3 개 장은 특히 문서화된 절차, 자격요건을 갖춘 직원, 임상 데이터의 접근제한 규정 등에 대해 기술한다. 네 번째 장에서는 CRO (Contract Research Organization)와의 데이터관리 상호작용에 대 해 이야기한다. 이러한 상호작용은 명확하게 규정되 어 있지 않으며 감사 받는 일도 거의 없지만 매우 중 요한 기반 구조를 구성한다. 거의 모든 기업들은 데이 터관리를 위해 어느 시점에선가 $\mathrm{CRO}$ 를 이용하며, 데 이터관리 전반을 $\mathrm{CRO}$ 를 통해 처리하기도 한다.

3 부는 “CDM 시스템"은 $\mathrm{EDC}$ 시스템을 포함하여, 많은 데이터 관리자들이 사용하고 있는 컴퓨터 시스 템들과 그 시스템들을 지원하는 데 필요한 특정 절차 들에 초점을 두고 있다. 모든 데이터 관리자들은 컴퓨 터 소프트웨어 어플리케이션으로 작업을 한다. 이들
은 그 시스템을 선정하거나, 실행, 혹은 설정하는데 관여할 수도 있고 그렇지 않을 수도 있다. 다음 장들 에서는 데이터 관리자들이 접하게 되는 소프트웨어 시스템의 유형에 대해 살펴보고, 어떻게 이런 시스템 들이 제품화 되는지에 대해 논의해 볼 것이다. 소프트 웨어 개발의 빠른 속도와 전자 데이터 수집 시스템 업체의 빠른 성장(과 실패)이라는 상황 속에서 대부 분의 데이터 관리자들은 최소한 지엽적인 문제에서라 도, 업체 선정과 새로운 시스템의 유효성 검증에 관여 하게 된다.

시스템 선정과 유효성 검증 차원의 논의는 당연히 책 한 권 분량만큼도 이루어질 수 있다. 다음 장들은 세부사항이나 세밀한 절차까지 기술하지 않고 전체적 인 조망을 제공하는 데 그 목적을 둔다.

이 책에서는 임상시험과 임상연구에서 높은 데이터 품질을 유지하기 위하여 어떤 절차와 문서를 개발하 여야 하는지에 대한 내용을 제시하고 있다. 그러나, 이것이 데이터를 잘 관리하는 것이 오직 한 가지 방 법만이 있다는 것을 의미하는 것은 아니다. 과제를 수 행하는 데에는 여러 방식들이 있으며, 어떤 방식을 사 용하더라도 데이터를 잘 보존하고 데이터 분석 능력 을 확실히 보증할 수 있다. 오히려 이러한 다양성을 위해서 어떤 절차를 적용할 것인지에 대해 적절하고 실용적인 대안들을 서술하고 있다.

최인영 가톨릭대학교 의료경영대학원 iychoi@catholic.ac.kr 